BNWL-2189

NRC- $1 \& 3$

\title{
Verification of Fuel Centerline Thermocouple Readings Through Response to Linear Power Decreases
}

by

D. D. Lanning

C. R. Hann

April 1977

Prepared for

Nuclear Regulatory Commission

Division of Reactor Safety Research

Fuel Behavior Research Branch

\section{Battelle}

Pacific Northwest Laboratories 
NOTICE

This report was prepared as an account of work sponsored by the United States Government. Neither the United States nor the United States Nuclear Regulatory Commission, nor any of their employees, nor any of their contractors, subcontractors, or their employees, makes any warranty, express or implied, or assumes any legal liability or responsibility for the accuracy, completeness or usefulness of any information, apparatus, product or process disclosed, or represents that its use would not infringe privately owned rights.

\author{
PACIFIC NORTHWEST LABORATORY \\ operated by \\ BATTELLE \\ for the \\ ENERGY RESEARCH AND DEVELOPMENT ADMINISTRATION \\ Under Contract EY-76-C-06-1830
}

\author{
Printed in the United States of America \\ Available from \\ National Technical Information Service \\ U.S. Department of Commerce \\ 5285 Port Royal Road \\ Springfieid, Virginia 22151
}

Price: Printed Copy \$__ ; Microfiche $\$ 3.00$

$\begin{array}{lc}\text { - Pages } & \text { NTIS } \\ 001-025 & \text { Selling Price } \\ 026-050 & \$ 4.50 \\ 051-075 & \$ 5.00 \\ 076-100 & \$ 5.50 \\ 101-125 & \$ 6.00 \\ 126-150 & \$ 6.50 \\ 151-175 & \$ 7.00 \\ 176-200 & \$ 7.75 \\ 201-225 & \$ 8.50 \\ 226-250 & \$ 8.75 \\ 251-275 & \$ 9.00 \\ 275-300 & \$ 10.00 \\ & \$ 10.25\end{array}$


VERIFICATION OF FUEL CENTERLINE THERMOCOUPLE READINGS THROUGH RESPONSE TO LINEAR POWER DECREASES

by

D. D. Lanning

C. R. Hann

\section{Apri1 1977}

Prepared for:

Nuclear Regulatory Commission Division of Reactor Safety Research

Fuel Behavior Research Branch

BATTELLE

Pacific Northwest Laboratories

Richland, Washington 99352 

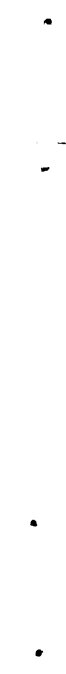


\section{CONTENTS}

LIST OF FIGURES. . . . . . . . . . . . . .

LIST OF TABLES ..................... $i{ }_{i}$

I - SUMMARY AND CONCLUSIONS. . . . . . . . . . . . . 1

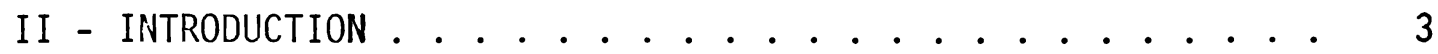

III - ANALYSIS OF QUASI-STEADY-STATE

TIME DERIVATIVE OF CENTERLINE

TEMPERATURE .................... 7

IV - IFA-431 POWER DROP ANALYSIS. . . . . . . . 13

V - RECOMMENDATIONS FOR FUTURE WORK........... 19

REFERENCES ...................... 22

APPENDIX A: NOTATION AND SI UNITS .......... A.1

APPENDIX B: DERIVATION OF THE CENTERLINE TEMPERATURE

RESPONSE TO A LINEAR DECREASE IN POWER. . . . . B. 1

APPENDIX C: REVIEW OF THE TEST FOR EQUALITY OF SLOPE

OF TWO LEAST SQUARES FIT LINES. . . . . . . . C. 1

APPENDIX D: RAW AND NORMALIZED DATA, AND REGRESSION

RESULTS .................. D. . . . 


\section{LIST OF FIGURES}

1 Schematic of Instrumented Fuel Assembly - IFA-431. . . . . 4

2 Qualitative Expected Behavior of $\mathrm{q}_{\mathrm{N}}$ and $\mathrm{T}_{\mathrm{N}}$....... 10

3 Normalized Data for TF2, Run 3........... . . 15

LIST OF TABLES

1 Test Parameters in IFA-431 . . . . . . . . . . . 5

2 IFA-431 Power Drops. . . . . . . . . . . . . . 13

3 Summary of Regression Results. . . . . . . . . . . 16

4 One-Sided 95\% Significance Interval for Centerline Temperature (In Degrees C) .............. 16

5 Estimated True Centerline Temperature Minus Initial Thermocouple Reading (In Degrees C). . . . . . . . 17

6 Frequency Distribution for the Data in Table 5. . . . . 18 


\section{VERIFICATION OF FUEL CENTERLINE THERMOCOUPLE READINGS \\ THROUGH RESPONSE TO LINEAR POWER DECREASES}

\section{I - SUMMARY AND CONCLUSIONS}

A method is presented whereby the true value and $95 \%$ confidence limits for fuel centerline temperatures are estimated from fuel thermocouple response to a linear decrease in rod power. Furthermore, it is shown that for moderate power decreases, these estimates are independent of uncertainties in the fuel rod thermal properties (including its gap conductance). The estimates are also independent of the absolute values of the initial thermocouple reading and power level.

Data is presented from power decreases on the U.S. Nuclear Regulatory Commission - Battelle Pacific Northwest Laboratories assembly IFA-431 in the Halden reactor. The reactor power was 1 inearly decreased approximately $20 \%$ in 30 seconds on several different occasions. The one-sided $95 \%$ confidence limits on centerline temperature from analysis of these runs varied from 67 to 292 C, depending on the run, the rod, and the power level. However, in 33 of the 40 cases examined, thermocouples agreed with the estimated true value centerline temperature within $80 \mathrm{C}$.

Future work is recommended which could narrow the confidence limits and provide an independent measure of the fuel-to-cladding gap conductance. 


\section{II - INTRODUCTION}

This report discusses the relationship between time-varying and steadystate fuel temperature measurements from Halden Reactor instrumented fuel assembly IFA-431. The design and fuel preparation for IFA-431 was done by Battelle-Northwest under the sponsorship of the USNRC. A major purpose of the test was to reduce the present uncertainty in stored energy calculations by gaining more precise measurements of fuel-clad gap conductance. That meant that uncertainty on factors that affect gap conductance (such as rod power, fuel thermal conductivity, gap size, and fill gas composition and pressure) had to be minimized. Careful preparation and precharacterization of the fuel was part of this effort; another part was the development of cross-checks on the power and fuel temperature data.

In particular this report shows that time-varying fuel thermocouple and assembly power measurements provide a cross-check on the accuracy of indicated steady-state fuel temperatures. Good reasons exist for seeking such a cross-check. There is continuous uncertainty in thermocouple performance, due to the possibility of shunting along the length, axial temperature gradient effects, and response change due to radiation effects.

A sketch of the 6-rod, IFA-431 assembly appears as Figure 1. A11 of the rods consisted of $10 \%$ enriched $\mathrm{UO}_{2}$ pellets clad in Zircaloy-4 tubing, with nominal dimensions $0.01279 \times 0.01090 \mathrm{~m}(\mathrm{OD} \times \mathrm{ID})$. The rods differed in gap size, fill gas and fuel density, as indicated in Table 1.

The assembly carried 12 fuel thermocouples and 6 vanadium neutron detectors, in two coplanar sets, as shown in Figure 1. The arrangement of neutron detectors facilitated axial and radial definition of the thermal neutron flux in the assembly. 


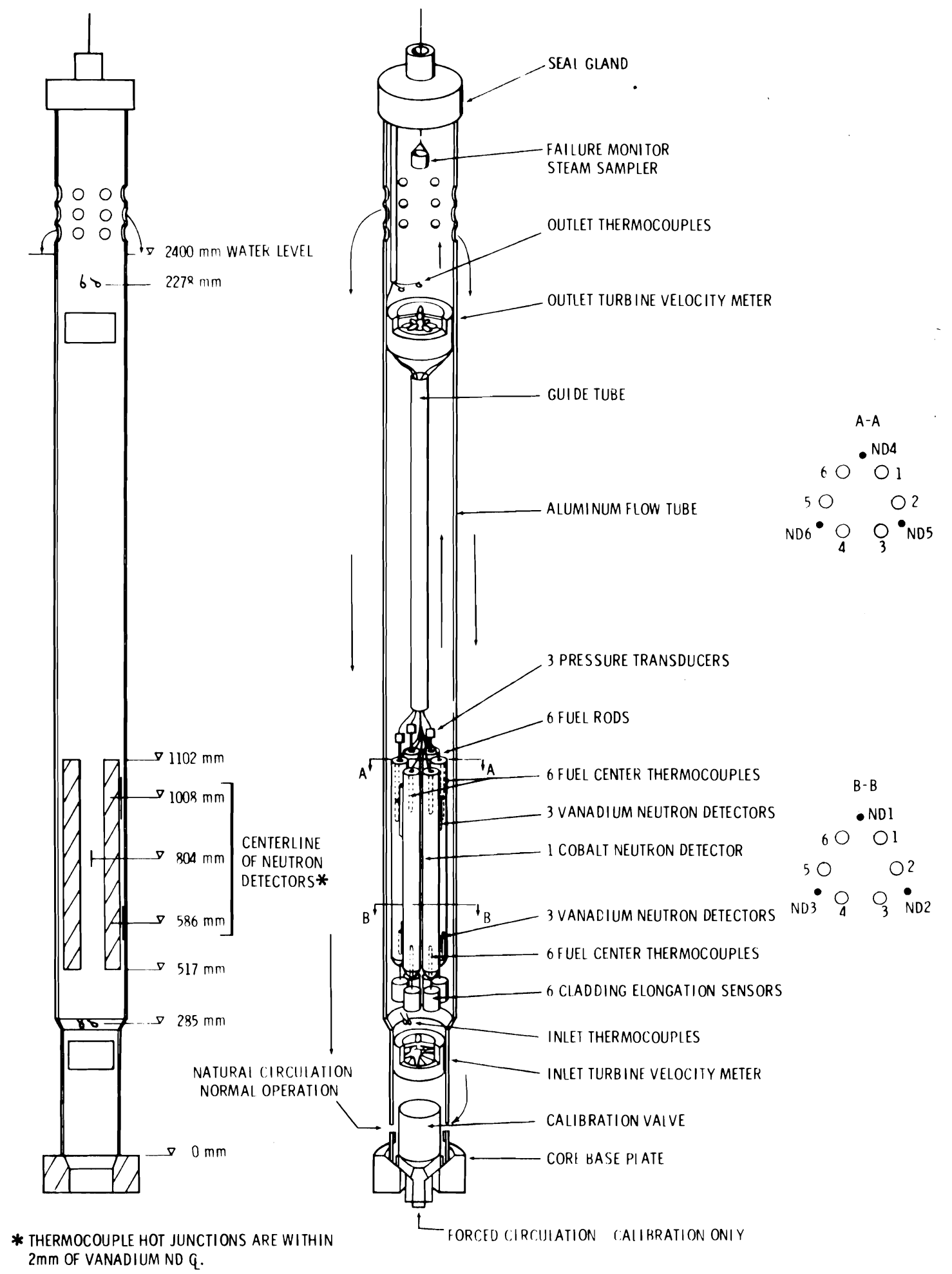

FIGURE 1. Schematic of Instrumented Fuel Assembly--IFA-431 
TABLE 1. Test Parameters in IFA-431

\begin{tabular}{|c|c|c|c|}
\hline $\begin{array}{c}\text { Rod } \\
\text { Number }\end{array}$ & $\begin{array}{l}\text { Density of } \\
\text { UO }\end{array}$ & $\begin{array}{l}\text { Diametral } \\
\text { Capa } \star \star \star \\
\text { I․ } 10^{-4}\end{array}$ & $\begin{array}{l}\text { Fill Gas } \\
(\text { all at. } 1 \mathrm{~atm} \\
\left.\text { at } 293^{\circ} \mathrm{K}\right)\end{array}$ \\
\hline 1 & 95 & 2.3 & $\mathrm{He}$ \\
\hline 2 & $9 b$ & 3.8 & $\mathrm{He}$ \\
\hline 3 & 95 & 0.5 & $\mathrm{He}$ \\
\hline 4 & 95 & 2.3 & $\mathrm{Xe}$ \\
\hline 5 & $92 \% \mathrm{~S}^{*}$ & 2.3 & $\mathrm{He}$ \\
\hline 6 & $92 \% U^{*}$ & 2.3 & $\mathrm{He}$ \\
\hline
\end{tabular}

\footnotetext{
* The $92 \%$ S fuel was stable with respect to probable in-reactor densification; the $92 \% \mathrm{U}$ was unstable, and was expected to densify.

** The values for diametral gap (i.e., the cladding ID less the pellet diameter) are for the asfabricated fuel rods at room temperature.
}

The assembly also carried a cobalt neutron detector, which has a response time to flux changes on the order of milliseconds and was capable of following and recording rapid relative changes in power. During special power changes, the cobalt detector output was recorded, along with that from al1 12 thermocouples, on a fast-scan system that records a complete data set every $3 \mathrm{sec}$. This was the feature that enabled the cross-check on centerline temperature described in the next section. 


\section{II - ANALYSIS OF QUASI-STEADY-STATE TIME DERIVATIVE OF CENTERLINE TEMPERATURE (SLOPE ANALYSIS)}

The time variation of fuel temperatures offers a measure of the fuel centerline temperature which is independent of the measured steady-state value. To see why this is true, consider a very simplified model of a fuel rod: consider it to be a lump characterized by a volumetric average temperature $\bar{T}$, surface area $A$, conductance $H$, heat capacity $C$, volume $V$, density $d$, and length $L$, producing a power units per unit length.* The steady-state heat balance equation for this model is simply

"Heat produced $=$ Heat lost"

or,

$$
q L=H A\left(\bar{T}-T_{\infty}\right) \text {, where } T_{\infty} \text { is the coolant temperature. }
$$

The time-varying equation for the model is (per unit time, $t$ ),

"Change in stored energy $=$ Heat produced - Heat lost"

or,

$$
d V C \frac{d \bar{T}}{d t}(t)=q(t) L-H A\left(\bar{T}-T_{\infty}\right) .
$$

We will now investigate a specific choice for $q(t)$, namely linear variation with time. This choice results in a linear change in temperature with time (after transient terms have died away). Furthermore, as we shall see, the relative change in the quantity $\left(\bar{T}-T_{\infty}\right)$ is equal to the relative change

* Sse Appendix A for a complete listing of the variables discussed in this report, the symbols used for them, and their appropriate SI units. 
in power, per unit time. This result occurs irrespective of the particular conductivity, conductance, or flux depression of a given rod.*

The advantages of the foregoing will be used to fix a limit of error on true $T_{0}$ given $q$. This uncertainty will be found to involve (in a straightforward way) only the uncertainties in relative changes of $T_{0}$ and $q$, and not the uncertainties in their absolute values. Furthermore the uncertainties in conductivity and conductance will not be involved.

The particular choice proposed for local rod power variation with time, i.e.

$$
q(t)=a+b t
$$

does not make the transient equation of heat transfer for a fuel rod any more tractable analytically. It is still highly nonlinear. However, as shown in Appendix $B$, approximations can be made which do allow an analytical solution for the time variation in quasi-steady state of the centerline temperature. In this section we will follow through the solution of the lumped-parameter model (Equation 2) for the case of linear change in rod power. The main features and the conclusion will be the same as that found in Appendix B, without especially cumbersome mathematics.

Recall that Equations (1) and (2) were

$$
\begin{array}{ll}
\mathrm{q}_{i} \mathrm{~L}=\left(\bar{T}_{i}-\mathrm{T}_{\infty}\right) H A & \text { (steady-state) } \\
\left(\frac{\mathrm{d} V \mathrm{C}}{\mathrm{HA}}\right) \frac{\mathrm{d} \overline{\mathrm{T}}}{\mathrm{dt}}=\frac{\mathrm{q} L}{\mathrm{HA}}-\left(\bar{T}-\mathrm{T}_{\infty}\right) & \text { (transient) }
\end{array}
$$

* Provided that the effective values of these quantities do not change significantly in the course of the power change. Appendix $B$ discusses the adequacy of this assumption for the data in this report. 
Define $q_{N}$ as $q_{N}=q L / H A\left(\bar{T}_{i}-T_{\infty}\right)$ such that

$$
1=q_{i} L / H A\left(\bar{T}_{i}-T_{\infty}\right)=q_{N_{i}} \text { (from the steady-state equation) }
$$

If one defines

$$
T_{N}=\frac{\bar{T}-T_{\infty}}{\overline{T_{i}}-T_{\infty}}
$$

and divides the transient equation by $\left(\bar{T}_{i}-T_{\infty}\right)$, one obtains

$$
\left(\frac{d V C}{H A}\right) \frac{d T_{N}}{d t}=q_{N}-T_{N}
$$

or

$$
\frac{1}{Z} \frac{d T_{N}}{d t}=q_{N}-T_{N}, Z=H A / d V C=\text { time constant }
$$

Now let

$$
\begin{aligned}
a_{N}(t)=1+b t, \text { where } b=\text { specified power "slope" } \\
T_{N}=1+\Delta T_{N}(t), \quad \Delta T_{N}(t)=\begin{array}{l}
\text { temperature response (to be } \\
\text { determined) }
\end{array}
\end{aligned}
$$

Substituting in Equation (4) and eliminating steady-state terms yields

$$
\frac{1}{Z} \frac{d}{d t}\left(\Delta T_{N}\right)=b t-\Delta T_{N}(t)
$$

with initial condition

$$
\Delta T_{N}(0)=0
$$

Laplace transformation yields an algebraic equation:

$$
\frac{1}{Z}\left[S_{\Delta} T_{N}^{*}(s)-\Delta T_{N}(0)\right]=\frac{b}{s^{2}}-\Delta T_{N}^{*}
$$

or

$$
\Delta T_{N}^{*}=\frac{b Z}{S^{2}(S+Z)}
$$


Now our concern will be with $\frac{d \Delta T}{d t}$, the Laplace transform of which in this case will be just $S \Delta T_{N}{ }^{*}(s)$. So multiply both sides of (5) by "s" to obtain

$$
S \Delta T_{N}^{*}=\frac{b}{S(S+Z)}
$$

Taking the antitransformation of both sides,

$$
\frac{d}{d t}\left(\Delta T_{N}\right)=b\left(1-e^{-z t}\right) \quad \text { (See Reference } 1 \text { for example) }
$$

In quasi-steady state, we have

$$
\frac{d}{d t}\left(\Delta T_{N}\right)=b
$$

Equation ( 6 ) says that as $t$ gets larger than $\sim 3 / Z$, the change/unit time in normalized relative temperature is equal to the slope of normalized power regardless of the value of the conductance or the absolute value of $q$ or $\bar{T}$. Appendix $B$ comes to this same conclusion for the centerline temperature of the actual fuel rod. A plot of normalized temperature and power should appear as in Figure 2.

Now suppose, when actual data is plotted in this way, the slopes of least-squares-fit 1 ines are unequal to a statistically significant degree. This means that the two vertical scales drawn in Figure 2 do not in fact coincide. Furthermore, the degree to which the slopes do not match is directly proportional to the degree to which the scales do not match. For example, if the slopes do not match to the extent of $10 \%$, then $T_{i}$, the initial thermocouple reading, is incorrect by $10 \%$ of the quantity $\left(T_{i}-T_{\infty}\right)$, which is the scale factor for the normalized temperature. 
We are now in a position to consider actual data, calculate typical limits of error, and compare with typical limits of error from steady-state calculations. That is the subject of the next section.

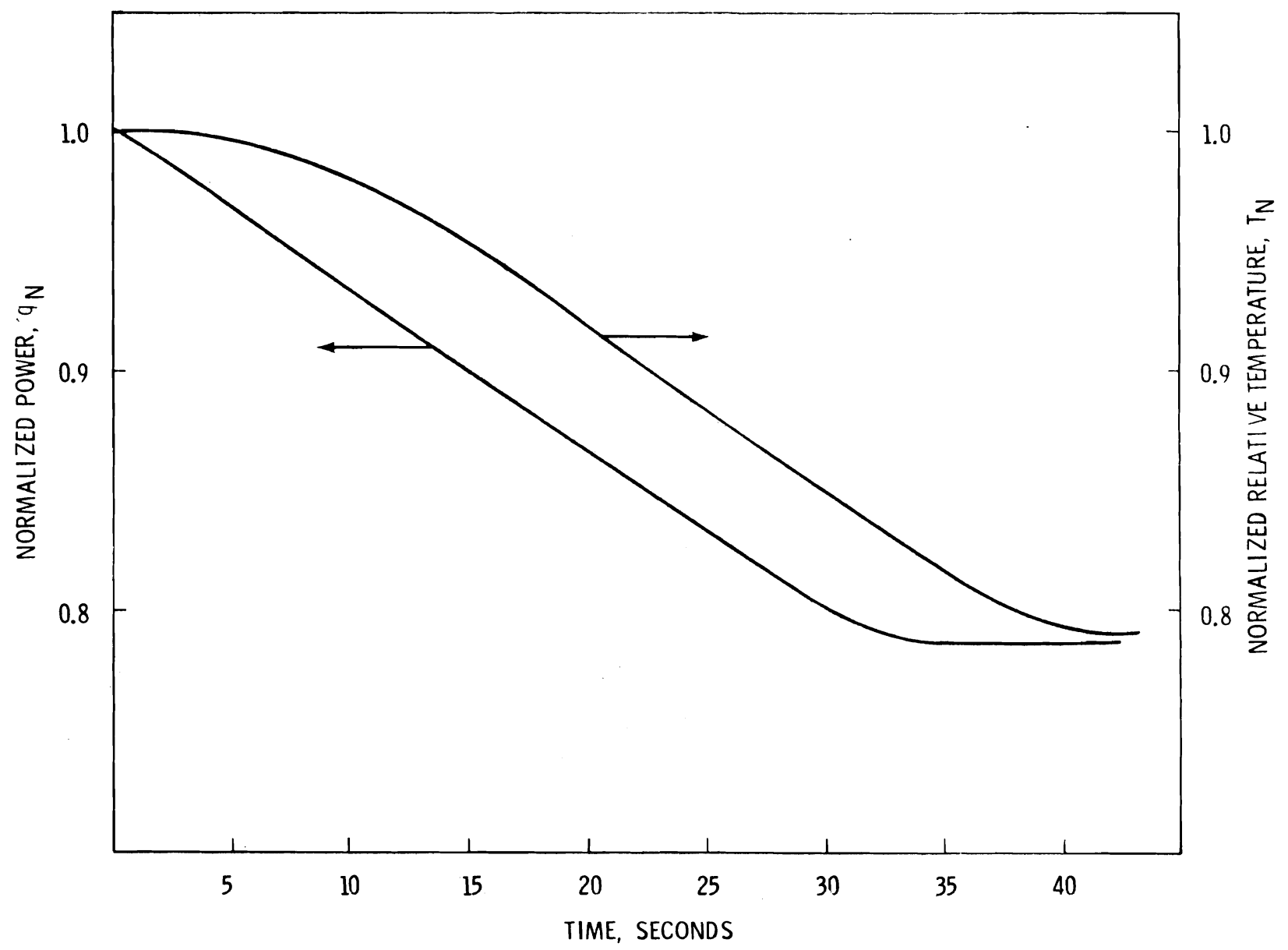

FIGURE 2. Qualitative Expected Behavior of $q_{N}$ and $T_{N}$ 


\section{IV - IFA-431 POWER DROP ANALYSIS}

The power changes used to create time-temperature data consisted of power decreases of $20 \%$ in approximately $30 \mathrm{sec}$. These power decreases were accomplished by control rod movement far from IFA-431. The whole reactor appeared to change power quite uniformly, based on the output of several widely spaced cobalt neutron detectors. A set of 3 such power drops were run after each operating month. The numbering system used by Halden to designate these power drops, and the dates on which they occurred, are shown in Table 2.

TABLE 2. IFA-431 Power Drops

$\begin{array}{ccc}\begin{array}{c}\text { Halden } \\ \begin{array}{c}\text { Run } \\ \text { Number }\end{array}\end{array} & \text { Date } & \begin{array}{c}\text { Approximate } \\ \text { Burnup } \\ \text { (MWd/MTU) }\end{array} \\ 1 & 6 / 22 / 75 & 0 . \\ 3 * & 6 / 22 / 75 & \\ 5 & 6 / 22 / 75 & \\ 7 & 6 / 26 / 75 & 0 . \\ 9 & 6 / 26 / 75 & \\ 11 * & 6 / 26 / 75 & 1,000 \\ 13 * & 8 / 8 / 75 & \\ 15 & 8 / 8 / 75 & \\ 17 * & 8 / 8 / 75 & 2,000 \\ 19 & 9 / 10 / 75 & \\ 21 * & 9 / 10 / 75 & \\ 23 & 9 / 10 / 75 & \end{array}$

* An asterisk (*) marks runs which were sufficiently linear for this report. 
Sample data from Rod 1 (the typical BWR rod) is presented in Figure 3, in normalized form. The data for this figure is that for thermocouple TF 2 from Run 3, tabulated in Appendix D.

Appendix $D$ contains a listing of raw and normalized data from all the "1 inear" power drops (Runs $3,11,13,17,21$ ). The results of least-squares fitting of straight lines to the most linear portions of these drops are also presented in Appendix D. These tables show the slope of the least-squares-fit 1 ine for the power and for each of the eight thermocouples examined.* For each thermocouple they also show the difference between the thermocouple (temperature) slope and the power slope, and the value of this difference which is statistically significant (from a one-sided " $t$ " test) at the $95 \%$ confidence level. The basis for this latter value is reviewed in Appendix $C$.

Table 3 below summarizes these results by showing, for each thermocouple and each selected power drop, the difference between the temperature and power slopes. This difference is expressed as a percentage of the statistically significant difference. $A(+)$ indicates the temperature slope is greater than the power slope and a(-) indicates that the temperature slope is less than the power slope. One would expect these percentages to be randomly distributed in both sign and magnitude. Note that the significant intervals are generally 15 to $20 \%$ of the slope values, which means that the "detection limit" of erroneous thermocouple readings with the present data is about $15-20 \%$ of $\left(T_{0}-T_{\infty}\right)$. These limits (one-sided) are presented in Table 4. Appendix $C$ gives a sample calculation for the entries in Table 4 . These limits are comparable to the $\pm 170^{\circ} \mathrm{C}$ estimated as a $95 \%$ confidence limit for $\mathrm{T}_{0}$ calculated

* Data from Rods 2 and 4 was excluded, since these rods had too much thermal inertia to come into quasi-steady state during the short power drops discussed here. 


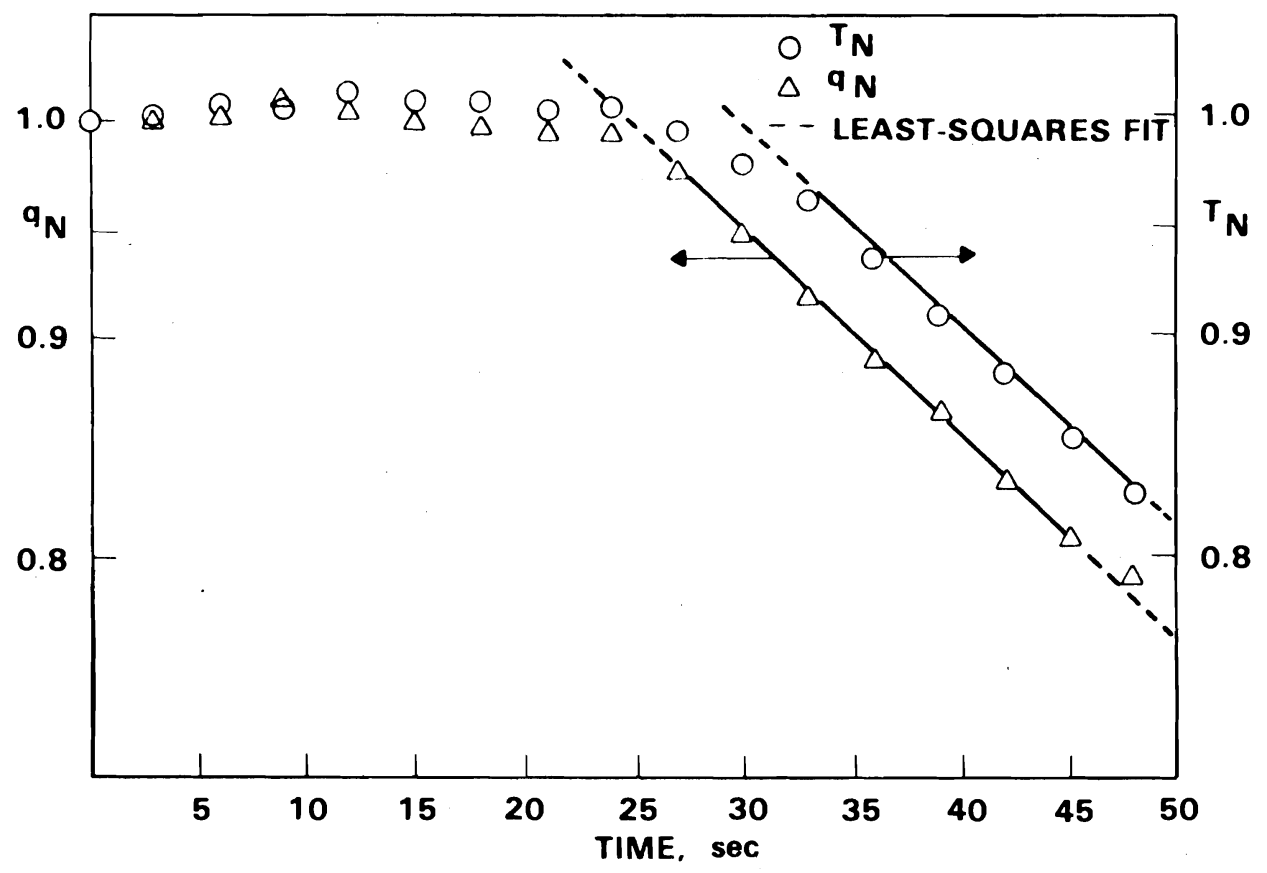

FIGURE 3. Normalized Data for Thermocouple TF2, Run 3 


\section{TABLE 3. Summary of Regression Results}

TABLE 4. One-Sided 95\% Significance Interval for Centerline Temperature (in Degrees C)

\begin{tabular}{|c|c|c|c|c|c|}
\hline Thermocouple & Run 3 & Run 11 & Run 13 & Run 17 & Run 21 \\
\hline TF 1 & 86 & 137 & 115 & 102 & 146 \\
\hline TF 2 & 109 & 174 & 99 & 148 & 201 \\
\hline TF 5 & 67 & 107 & 58 & 68 & 148 \\
\hline TF 6 & 73 & 145 & 85 & 107 & 148 \\
\hline TF 9 & 65 & 135 & 87 & 99 & 142 \\
\hline TF 10 & 96 & 198 & 134 & 178 & 215 \\
\hline TF 11 & 67 & 146 & 84 & 115 & 150 \\
\hline TF 12 & 97 & 292 & 111 & 214 & 218 \\
\hline
\end{tabular}

from steady-state conditions (Reference 2). In addition the estimates of $T_{0}$ from the power drop data are completely independent of either steady-state readings or calculations. They thus form a cross-check on the thermocouple readings which is capable of detecting significant thermocouple bias or decalibration. This has the effect of removing some bias from the gap conductance values which are inferred from the thermocouple readings. 
Table 5 presents the difference between initial thermocouple readings and estimated true centerline temperatures. Table 5 was produced by simply combining the results of Tables 3 and 4 . Table 6 shows the frequency distribution of the data in Table 5. From Table 6 we see that the median of the data is very nearly zero, and that data is pretty evenly scattered in the range $\pm 80 \mathrm{C}$, with a mode at $-10 \mathrm{C}$. The mean of the data is $+16 \mathrm{C}$, and its standard deviation is 62 C.

TABLE 5. Estimated True Centerline Temperature Minus Initial Thermocouple Reading (in Degrees C)

\begin{tabular}{|c|c|c|c|c|c|}
\hline Thermocouple & Run 3 & Run 11 & Run 13 & Run 17 & Run 21 \\
\hline TF 1 & -16 & +65 & +14 & -43 & -34 \\
\hline TF 2 & -61 & +36 & +2 & -74 & -87 \\
\hline TF 5 & +26 & +103 & +12 & -9 & -1 \\
\hline TF 6 & +71 & +167 & +34 & -9 & -55 \\
\hline TF 9 & -24 & +54 & +26 & -4 & -8 \\
\hline TF 10 & -42 & +161 & +94 & +18 & +68 \\
\hline TF & -4 & +78 & +33 & -28 & -14 \\
\hline TF 12 & -62 & +139 & +76 & -8 & -66 \\
\hline
\end{tabular}

Note that the three values in excess of $120 \mathrm{C}$ all occur in Run 11. This indicates that Run 11 may involve a power slope estimate that is simply too low. If data from this run is excluded, the remaining data has a standard deviation of $45 \mathrm{C}$ and a mean of $-4 \mathrm{C}$. This latter data can be said to indicate that the thermocouple readings agree with the estimated true value within $80 \mathrm{C}$ at the $95 \%$ confidence level. 
TABLE 6. Frequency Distribution for Data in Table 5

Sub-Range,

Degrees C

Bel ow -80

-80 to -60

-60 to -40

-40 to -20

-20 to 0

0 to +20

+20 to +40

+40 to +60

+60 to +80

+80 to +100

+100 to +120

Above 120
Number of

Data Points in the Sub-Range

\section{1}

4

3

3

9

4

4

2

5

1

1

3 


\section{$V$ - RECOMMENDATIONS FOR FUTURE WORK}

There are several ways the results in this report could be improved or extended in future experiments. We will discuss only two aspects here: 1) ways to narrow the confidence limits on centerline temperature and 2) ways to derive estimates of the gap conductance.

\section{Narrowing the Confidence Limits}

From the experience so far it is apparent that the overall rate of $0.67 \% / \mathrm{sec}$ is nearly ideal for a power decrease; steeper rates produce too few data points in the linear region, and shallower rates produce power histories that are decidedly nonlinear. It is also apparent that increasing the number of data points taken per run will not decrease the residual standard deviation, which determines the confidence limits. Thus the only avenue open for narrowing the confidence limits is to make the power decreases more truly linear, which means altering the method by which they are achieved. This could probably be done in the helium-3 rig in the Halden reactor. It could also be done by surrounding the assembly by a rotatable shroud (similar to the shroud on IFA-429). The shroud could be tapered or graded in composition around its circumference, such that as it rotates it casts a linearly increasing shadow to neutron radiation across a rod site. Juxtaposition of a cobalt detector near the rod site would adequately determine the variation of the flux at the rod site since it is the slope of the power that is important, not its instantaneous absolute value.

\section{Deriving Gap Conductance Values}

The data in this report indicated that the limiting value of the power-to-centerl ine-temperature transfer function does not vary typically 
more than $25 \%$ over a power range of $20 \%$ and its variation is typically less than $3 \%$ over a power range of $10 \%$. This is not a new or starting result. But it does point to a way to independently estimate the gap conductance. If a rapid but accurately calibrated change in power were made (say $10 \%$ in less than $5 \mathrm{sec}$ ) then the centerline temperature behavior about $20 \mathrm{sec}$ after that change would be exponential with a time constant directly related to the ratio of the fuel-to-coolant conductance divided by the fuel conductivity. This independent check on both conductivity and conductance could be achieved by the same rotatable shroud described above, by simply making a rapid twist. Again, the fact that the neutron detector recording the power change is not exactly at the rod site will not affect the results, since it is the ultimate relative value of the power change that is important, not the instantaneous absolute value of the power.

Note that the shroud could be graded axially rather than circumferentially, and lowered past a thermocouple elevation at constant speed to produce linear and rapid power variations. 


\section{ACKNOWLEDGEMENTS}

The authors wish to thank the following persons for their review and comments on this report.

$$
\begin{aligned}
& \text { Mr. R. Williford - Battelle-Northwest (Fuels Design) } \\
& \text { Mr. A.R. 0lson - Battelle-Northwest (Statistics) } \\
& \text { Dr. B. Scheffler - Joint Center for Graduate Study } \\
& \text { (Heat Transfer) }
\end{aligned}
$$




\section{REFERENCES}

1. W. T. Thompson, Laplace Transformation. Prentice-Ha11, 1960.

2. D. D. Lanning and C. R. Hann, "Verification of Fuel Thermocouple Readings by Analysis of Transient Response." Trans. Am. Nucl. Soc., 24: 156-157, 1976.

3. C. E. Beyer, C. R. Hann, et a1., GAPCON-THERMAL-2: A Computer Program for Calculating the Thermal Behavior of an Oxide Fuel Rod. BNWL-1898 (1975).

4. J. A. Dearien et al., FRAP-S: A Computer Code for the Steady-State Analys is of Oxide Fuel Rods. TFBP-TR-154, Dec. 1976.

5. R. Lowel1 Wine, Statistics for Scientists and Engineers. Prentice-Ha11, Englewood Cliffs, N.J., 1964.

6. A. Bjorck and J. Golub, "I terative Refinement of Linear Least-Squares Solution by Householder Transformations." BIT, Vol. 7 (Copenhagen), 1967. 
APPENDIX A

NOTATION AND SI UNITS 


\section{,}

: 
APPENDIX A

\section{NOTATION AND SI UNITS}

The variables discussed in this report are listed below, together with their symbol and appropriate SI units.

\begin{tabular}{|c|c|c|}
\hline Symbol & Meaning & SI Units \\
\hline A & Fuel rod surface area & $m^{2}$ \\
\hline$b$ & $\begin{array}{l}\text { "slope" of normalized power data, } \\
\text { i.e. } \frac{\mathrm{dq}_{\mathrm{N}}}{\mathrm{dt}}\end{array}$ & (fraction)/sec \\
\hline C & Effective fuel rod heat capacity & joules/kg-C \\
\hline$d$ & Fuel density & $\mathrm{kg} / \mathrm{m}^{3}$ \\
\hline G & $\begin{array}{l}\text { Rod power-to-centerline temperature } \\
\text { transfer function }\end{array}$ & $\mathrm{C} / \mathrm{W} / \mathrm{m}$ \\
\hline H & Fuel surface-to-coolant conductance & $w / m^{2}-c$ \\
\hline $\mathrm{L}$ & Fuel rod length & $\mathrm{m}$ \\
\hline$q$ & Rod linear power & $\mathrm{W} / \mathrm{m}$ \\
\hline$S$ & Laplace transform variable & \\
\hline$s_{r}$ & Residual standard deviation & varies \\
\hline$T_{0}$ & Centerline temperature & C \\
\hline T & Volumetric average temperature & C \\
\hline$T_{i}$ & Initial value of $T$ & c \\
\hline $\mathrm{T}_{\mathrm{N}}$ & Normalized relative temperature & C \\
\hline$T_{\infty}$ & Coolant temperature $(2240 \mathrm{C})$ & c \\
\hline$\Delta T(t)$ & Time-varying portion of temperature $T$ & c \\
\hline Z & Time constant for a fuel rod & $\sec ^{-1}$ \\
\hline
\end{tabular}



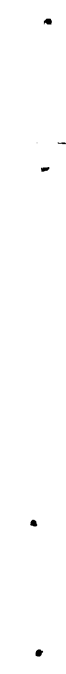
APPENDIX B

DERIVATION OF THE CENTERLINE TEMPERATURE

RESPONSE TO A LINEAR DECREASE IN POWER 
:

. 


\section{APPENDIX B}

\section{DERIVATION OF THE CENTERLINE TEMPERATURE RESPONSE TO A LINEAR DECREASE IN POWER}

In Part III of the text it was shown that

$$
\frac{d T_{N}}{d t}=\frac{d q_{N}}{d t} \text {, as } t \rightarrow \infty
$$

that is, the slope of the normalized relative (volumetric averaged) temperature approaches the slope of the normalized power. This result was derived for a lumped-parameter model of the fuel rod, under the assumption of temperatureindependent thermal properties. It is by no means obvious (nor is it generally true) that the same result holds for centerline temperature of real fuel rods whose thermal properties certainly are temperature dependent. It is the purpose of this Appendix to show that the result (B.1) does hold approximately for the tests reported, and that the degree of approximation is well within the 1 imits of error resultant from the intrinsic scatter in the data.

First, we shall derive the equivalent of (B.1) for the centerline temperature, $T_{0}$. Let $\quad T_{r}(t)=T_{r_{j}}+\Delta T(t)$ where, $T_{r}=T_{0}-T_{\infty}$

$$
q(t)=q_{j}+\Delta q(t)
$$

$i$ e., the sum of known initial components and unknown time varying components. Now let the fuel rod be characterized by a transfer function $G(s)$ relating $\Delta T_{r}(t)$ to $\Delta q(t)$, such that the Laplace transform of $\Delta T_{r}$ (i.e., the "output") is equal to the transform of $\Delta q$ (the "input") times this transfer function:

$$
\Delta T_{r}^{*}(s)=G(s) \Delta q^{*}(s)
$$


The transfer function of course contains all the aspects of the fuel rod (its fuel and clad thernal properties, its gap conductance, its geometry, its film coefficient and its flux depression), and is a very complicated and temperature-dependent function. But let $G_{Q}(s)$ be the effective transfer function at a given power level $q=Q$, so that $G_{Q}(s)$ is assumed independent of $\Delta T_{r}^{\star}(s)$. We will investigate the limitations of this assumption in a moment. Note that the temperature-dependent components of $G_{Q}$ have been evaluated at the steady-state temperature distribution at $q=Q$. Now let us take a power step all the way from $q=0$ to $q=Q$, and write down the Laplace transform of $\Delta T_{0}$, the resultant temperature rise. Our initial conditions are

$$
\begin{aligned}
& T_{r}=0 \\
& q_{j}=0, t \leq 0
\end{aligned}
$$

and

$$
\Lambda q=Q(t>0)
$$

Thus

$$
\Delta T_{r}^{*}=\frac{G(s) Q}{S}
$$

We know that this expression will only lead to a correct answer as $t \rightarrow \infty$ or $S \rightarrow 0$, since we are using $G_{Q}$ for the transfer function. Furthermore we know that as $t \rightarrow \infty, \quad \Delta T_{r} \quad\left(T_{Q}-T_{\infty}\right)$, where $T_{Q}$ is the steady-state centerline temperature at $q=Q$. Thus

$$
\lim _{t \rightarrow \infty}\left(\mathcal{L}^{-1} \Delta T_{r}^{*}\right)=Q \lim \mathcal{L}^{-1}\left(\begin{array}{c}
G_{Q} \\
\bar{s}
\end{array}\right)=T_{Q}-T_{\infty}=T_{r}^{Q}
$$

This result will be useful in a moment. 
Now consider a small, linear power decrease from power level $q=Q$. Variables $T_{r}$ and $q$ are

$$
\begin{aligned}
T_{r}(t) & =T_{r}^{Q}+\Delta T_{r}(t) \\
q(t) & =Q-b t
\end{aligned}
$$

so $\Delta q=-b t$. Note initial conditions are

$$
\begin{aligned}
\Delta q & =\Delta T_{r}=0 \\
\text { at } t & =0
\end{aligned}
$$

We can write down the transform of the resultant $\Delta T_{0}(t)$ as

$$
\Delta T_{r}^{*}=\frac{G_{Q} b}{s^{2}}
$$

We can also write down the transform of the time derivative of $\Delta T_{0}(t)$, since

$$
\mathcal{L}\left[\frac{d}{d t}\left(\Delta T_{r}\right)\right]=S \Delta T_{r}^{*}(s)-\Delta T_{r}(t=0)=S \Delta T_{r}^{*}
$$

Thus

$$
S \Delta T_{r}^{*}=\mathcal{L}\left[\frac{d}{d t}\left(\Delta T_{r}\right)\right]=\frac{b G_{Q}}{S}
$$

The quasi steady-state value of this derivative will be

$$
\lim _{\frac{d}{d t}}\left(\Delta T_{r}\right)=b \lim \left[\mathcal{L}^{-1}\left(\frac{G_{Q}}{S}\right)\right]
$$

Now let us divide B.3 by B.2:

$$
\left(\frac{1}{T_{Q}-T_{\infty}}\right)_{t \rightarrow \infty} \lim _{t \rightarrow \infty} \frac{d}{d t}\left(\Delta T_{r}\right)=\frac{b}{Q}=b_{N}
$$

If we define

$$
T_{N}=\frac{T_{r}-T_{\infty}}{T_{Q}-T_{\infty}}
$$


much as before, and recognize that

$$
\frac{d}{d t}\left(\Delta T_{1}\right)=\frac{d\left(T_{0}-T_{\infty}\right)}{d t}
$$

then we have, from B. 4

$$
\frac{d T_{N}}{d t}=b_{N} \text { as } t \rightarrow \infty
$$

that is, the slope of the normalized relative centerline temperature approaches the slope of the normalized power, under the assumption that $G_{Q}$ is independent of $\Delta T_{r}$. Note that it is the quantity

$$
\lim _{t \rightarrow \infty}\left[\mathcal{L}-1\left(\frac{G_{Q}}{S}\right)\right]
$$

that determines the quasi-steady state slope during a linear power decrease. Thus an examination of $T_{r}(t \rightarrow \infty)$ at different power levels would reveal the dependence of $G$ on $q$. This information could be used to determine "acceptable" ranges of linear power decreases, for which a constant (initial value) transfer function could be used. This examination of $G$ could be done experimentally by bringing the assembly up to a given power, waiting for and recording steadystate centerline temperatures, then increasing the power and recording the steady-state temperatures again. The process would be repeated for many different power levels. Quite comparable results, however, may be obtained by using a computer program such as GAPCON-II ${ }^{(3)}$ or FRAP-S ${ }^{(4)}$ which reliably incorporates all the temperature-dependent properties of the fuel rod. The results of such a procedure are presented in Table B.1, for computer input 
conditions appropriate to TF 2 at full reactor power. As can be seen, the transfer function does not change greatly over the typical range of the power drops described in this report. *

Similar analyses have been performed for all the thermocouple locations considered in this report, with similar results.

TABLE B.1. Apparent Limiting Values of Effective TF 2 Transfer Function

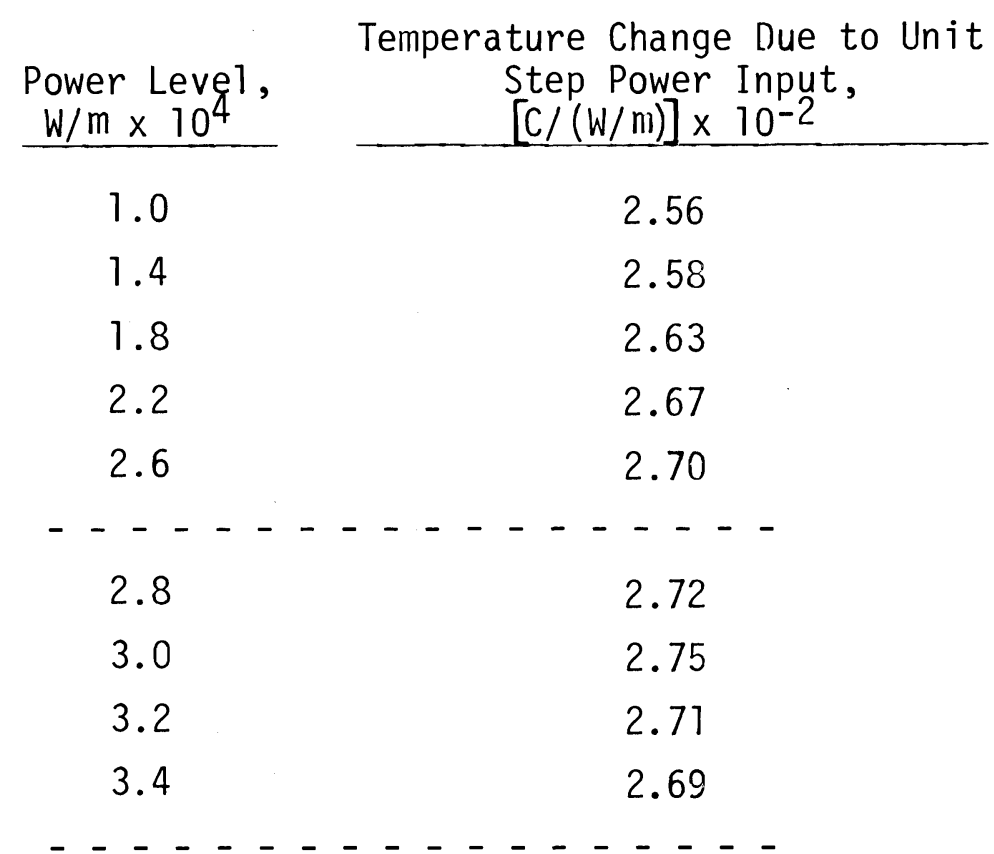

Note: The dashed lines represent the approximate limits of a typical power drop.

* In this example, the change is $<2 \%$ which leads to a $-6 \%$ bias in the slope of the temperature response to a perfectly linear power decrease. However, the confidence limits on power and temperature slopes are generally 2-3 times as large. 
APPENDIX C

REVIEW OF THE TEST FOR EQUALITY OF

SLOPE OF TWO LEAST SQUARES FIT LINES 

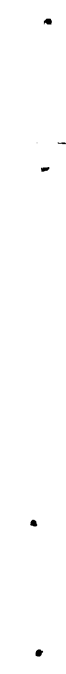


\section{APPENDIX C}

\section{REVIEW OF THE TEST FOR EQUALITY OF}

\section{SLOPE OF TWO LEAST SQUARES FIT LINES}

The selected normalized power data for each run is used to establish an estimated power slope by the familiar method of least squares fitting of a straight line. The computer program MARTHA ${ }^{*}$ was used to do this. Likewise, least-squares-fit lines were established for selected normalized temperature data from each thermocouple during each run. Now let $b_{1}$ be the power slope for a given run and $b_{2}$ be the slope of the normalized temperature for some specific thermocouple. Then it is a we11-known result that the quantity

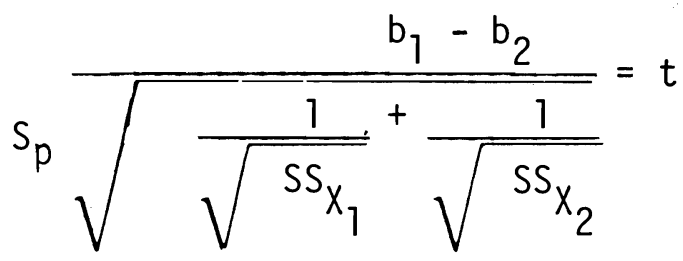

is distributed as " $t$ " with $\left(n_{1}+n_{2}-4\right)$ degrees of freedom where $n_{1}, n_{2}$ are the number of data points used for power and temperature, respectively (see, for example, Reference 5, p. 555). In the above quantity, $S_{p}$ represents the pooled standard deviation, which is defined from

$$
s_{p}^{2}=\frac{\left(n_{1}-2\right) s_{r_{1}}^{2}+\left(n_{2}-2\right) s^{2} r_{2}}{n_{1}+n_{2}-4}
$$

* MARTHA is a package of subroutines facilitating input and output from the main program described in Ref. 6. The "normal equations" of least-squares analysis are solved by an iterative technique, and the results manipulated to present confidence limits. 
where $s_{r_{1}}^{2}$ and $s_{r_{2}}^{2}$ are the "residual mean squares," i.e., the sum of the squared deviations from the least-squares-fit line, divided by $(n-2)$. Similarly $\mathrm{SS}_{\mathrm{X}_{1}}$ and $\mathrm{SS}_{\mathrm{X}_{2}}$ are the "adjusted sums of squares" of the independent variable $X$ (in this case, time). They are defined as

$$
\sum_{i=1}^{n}\left(x_{i}-\bar{x}\right)^{2}
$$

where $\bar{X}$ is the mean value for the particular data set.

As an example of the calculation of a significant difference in slopes at the $95 \%$ confidence level, consider the regression results 1 isted for TF 1 , Run 3 (Table D-3). We see that

$$
\begin{array}{ll}
\mathrm{n}_{1}=7 & \text { (Power) } \\
\mathrm{n}_{2}=5 & (\text { TF 1) } \\
\mathrm{SS}_{X_{1}}=252 & \\
\mathrm{SS}_{X_{2}}=90 & \\
\mathrm{~s}_{r_{1}}=0.00155 & \\
\mathrm{~S}_{r_{2}}=0.00188 .
\end{array}
$$

The pooled standard deviation is

$$
s p=\sqrt{\left(5 s_{r_{1}}^{2}+3 s_{r_{2}}^{2}\right) / 8}=0.00168 \text {. }
$$

Therefore

$$
\text { " } t \text { " }=\frac{b_{1}-b_{2}}{0.00168 \sqrt{\frac{1}{\sqrt{252}}+\frac{1}{\sqrt{90}}}}=\frac{b_{1}-b_{2}}{0.000690} \text {. }
$$

The critical " $t$ " for a one-sided test with 8 degrees of freedom is 1.860 . Therefore, the significant value for the difference in slopes $\left(b_{1}-b_{2}\right)$ is 
$(0.000690) \times 1.860=0.00128$. Since the power slope in this case was 0.00938 , the relative difference that is significant is

$$
\frac{0.00128}{0.00938}=13.6 \%
$$

This relative difference can be translated into a significance interval for a centerline temperature from the fact that the normalized temperature is proportional to $1 /\left(\mathrm{T}_{0}-\mathrm{T}_{\infty}\right)$. For this case $\mathrm{T}_{0}$ is $871 \mathrm{C}$, and $\mathrm{T}_{\infty}$ is taken as $240 \mathrm{C}$ for all cases. Thus the significance interval is

$$
13.6 \% \times(871-240)=86 C
$$

(cf. Table 4). 


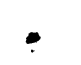


APPENDIX D

RAW AND NORMALIZED DATA, AND REGRESSION RESULTS 

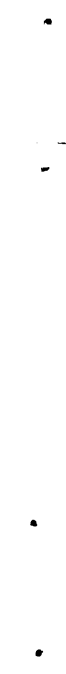


\section{APPENDIX D}

\section{RAW AND NORMAL IZED DATA, AND REGRESSION RESULTS}

The tables in this appendix occur in sets of three each. The first table of each set presents the actual cobalt neutron detector and thermocouple readings from a given power drop. The second table in the set presents the same data in normalized form, where power and measured centerline temperature have been normalized as

$$
T_{N}=\frac{T_{0}(t)-T_{\infty}}{T_{i}-T_{\infty}}, \quad T_{\infty}=240 \mathrm{C}
$$

and

$$
q_{N}=q(t) / q_{i}
$$

The dashed lines in tables of normalized data represent the limits of the linear portions of these data. The third table in each set presents the results of fitting a straight line through these linear portions by the method of least squares. This is called simple linear regression, and the "regression results" 1isted include the 1) slope of the regression line,2) the difference between the power slope and the slope from the temperature data of each thermocouple, and 3 ) the value of this slope difference that is significant at the $95 \%$ confidence level.*

Also included in the "regression results" tables are the residual standard deviation and the adjusted mean square of the time variable. These quantities determine the $95 \%$ significance interval, and they are defined and discussed in Appendix $C$.

* This is referred to as the "95\% significance interval." 
TABLE D-1. Power and Temperature Data for Run 3

(Temperatures in Degrees C)

Normalized

Cobalt

Time, $\begin{gathered}\text { Tetector } \\ \text { (sec) } \\ \text { Output }\end{gathered}$ TF 1 TF 2 TF 5 TF 6 TF 9 TF 10 TF 11 TF 12
TF

Time,
(sec) $\begin{gathered}\text { Detector } \\ \text { Output }\end{gathered}$

$\begin{array}{rrrrrrrrrr}0 & 1.0000 & 871 & 1079 & 704 & 890 & 879 & 1128 & 891 & 1130 \\ 3 & 1.0014 & 871 & 1081 & 704 & 890 & 879 & 1130 & 891 & 1130 \\ 6 & 1.0026 & 873 & 1081 & 705 & 891 & 880 & 1130 & 893 & 1131 \\ 9 & 1.0103 & 874 & 1082 & 706 & 891 & 881 & 1132 & 893 & 1132 \\ 12 & 1.0077 & 876 & 1083 & 708 & 895 & 882 & 1134 & 895 & 1135 \\ 15 & 0.9986 & 874 & 1083 & 708 & 892 & 881 & 1132 & 895 & 1132 \\ 18 & 0.9957 & 874 & 1082 & 706 & 891 & 881 & 1130 & 894 & 1133 \\ 21 & 0.9952 & 872 & 1079 & 705 & 889 & 880 & 1128 & 893 & 1130 \\ 24 & -0.9937 & 872 & 1078 & 704 & 889 & 879 & 1128 & 893 & 1130 \\ 27 & 0.9749 & 867 & 1073 & 704 & 883 & 875 & 1123 & 888 & 1123 \\ 30 & 0.9470 & 858 & 1060 & 698 & 872 & 867 & 1111 & 880 & 1111 \\ 33 & 0.9199 & 846 & 1046 & 690 & 854 & 854 & 1093 & 869 & 1094 \\ 36 & 0.8885 & 831 & 1027 & 680 & 834 & 839 & 1073 & 853 & 1075 \\ 39 & 0.8649 & 816 & 1006 & 668 & 814 & 822 & 1050 & 835 & 1052 \\ 42 & 0.8344 & 798 & 986 & 654 & 795 & 805 & 1027 & 817 & 1030 \\ 45 & -0.8056 & 779 & 961 & 640 & 772 & 787 & 1002 & 799 & 1005 \\ 48 & 0.7908 & 763 & 940 & 625 & 753 & 770 & 978 & 780 & 982 \\ 51 & 0.7950 & 745 & 930 & 612 & 743 & 761 & 964 & 771 & 969 \\ 54 & 0.7822 & 748 & 922 & 607 & 738 & 754 & 954 & 763 & 961 \\ 57 & 0.7777 & 742 & 915 & 604 & 732 & 748 & 943 & 757 & 951\end{array}$


TABLE D-2. Normalized Temperature Data for Run 3

\begin{tabular}{|c|c|c|c|c|c|c|c|c|}
\hline & & & & & & & & \\
\hline & $\overline{T F} 1$ & $\overline{T F 2}$ & TF 5 & TF 6 & TF 9 & TF 10 & TF 11 & TF 12 \\
\hline 0 & 00 & 000 & 0 & 0000 & 1. & 00 & 0000 & 1.0000 \\
\hline 3 & & 024 & 1. & 00 & 1.0000 & 23 & 0000 & 000 \\
\hline 6 & 032 & 24 & 1. & 175 & 16 & 23 & 31 & 1.0011 \\
\hline 9 & 1.0048 & 1.0036 & 1.0043 & 1.0015 & 1.0032 & 1.0046 & 1.0031 & 1.0022 \\
\hline 12 & 1.0079 & 1.0048 & 1.0086 & 1.0077 & 1.0047 & 1.0068 & 1.0061 & 1.0056 \\
\hline 15 & & 1. & 1.0 & 1.0 & 1. & & 61 & $1.00<2$ \\
\hline 18 & 1. & 6 & 1 & & & & & 1.0034 \\
\hline 21 & 1.0016 & 1.0000 & 1.0022 & 0.9985 & 1.0016 & 1.0000 & 1.0031 & 1.0000 \\
\hline 24 & 1.0016 & 0.9988 & 1.0000 & 0.9985 & 1.0000 & 1.0000 & 1.0031 & 1.0000 \\
\hline 27 & & 0.9 & 100 & 0.9892 & & & 154 & 0.9921 \\
\hline 30 & 0.9794 & 0.9774 & 0. & 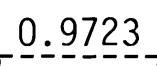 & 0.9812 & 0.9809 & 0.9831 & 0.9787 \\
\hline 33 & 0.9604 & 0.9607 & _0.9698 & 0.9446 & 0.9609 & ㅇ.9606 & ㅇ.9은? & ㅇ․95966 \\
\hline 36 & 9366 & 0.9380 & 0.9483 & 0.9138 & 0.9374 & 0.9381 & 0.9416 & 0.9382 \\
\hline 39 & 0.9128 & 0.9130 & 0.9224 & 0.8831 & 0.9108 & 0.9122 & 0.9140 & 0.3124 \\
\hline 42 & 43 & 0.8 & 922 & 0.8538 & & 863 & 363 & 0.8876 \\
\hline 45 & 0.8542 & 0.8594 & 0.8621 & 0.8185 & 0.8560 & 0.8581 & 0.8587 & 0.8596 \\
\hline 48 & $\underline{0} \underline{\underline{\theta}} \varepsilon$ & $-\underline{0}$. & 97. & -0.7899? & $\underline{0.8}$ & 11 & 95 & 으요근 \\
\hline 51 & 0.8003 & 0.8224 & 0.8017 & 0.7738 & 0.8 & $0 . \varepsilon$ & 0.8157 & 0.8191 \\
\hline 54 & 0.8050 & 0.8129 & 0.7909 & 0.7662 & 0.8044 & 0.8041 & 0.8034 & 0.8101 \\
\hline 57 & 0.7956 & 0.8045 & 0.7845 & 0.7569 & 0.7950 & 0.7917 & 0.7942 & 0.7989 \\
\hline
\end{tabular}


TABLE D-3. Regression Results for Run 3

\begin{tabular}{|c|c|c|c|c|c|}
\hline $\begin{array}{c}\text { Data } \\
\text { Source } \\
\end{array}$ & $\begin{array}{c}\text { Slope of } \\
\text { Best-Fit Line, } \\
\text { sec }^{-1}\end{array}$ & $\begin{array}{c}\text { Slope } \\
\text { Difference, } \\
\text { sec }^{-1} \\
\end{array}$ & $\begin{array}{c}\text { Significant } \\
\text { Slope } \\
\text { Difference, } \\
\text { sec-1 }^{-1} \\
\end{array}$ & $\begin{array}{l}\text { Residual } \\
\text { Standard } \\
\text { Deviation, } \\
\text { sec }^{-1} \\
\end{array}$ & $\begin{array}{c}\text { Adjusted } \\
\text { Mean Square } \\
\text { for Time, } \\
\text { sec }^{2} \\
\end{array}$ \\
\hline $\begin{array}{l}\text { Cobalt } \\
\text { Detector }\end{array}$ & 0.00938 & -- & -- & 0.00155 & 252 \\
\hline TF 1 & 0.00914 & -0.00024 & 0.00128 & 0.00188 & 90 \\
\hline TF 2 & 0.00870 & -0.00068 & 0.00122 & 0.00169 & 90 \\
\hline TF 5 & 0.00991 & +0.00053 & 0.00135 & 0.00208 & 90 \\
\hline TF 6 & 0.01040 & +0.00102 & 0.00105 & 0.00149 & 157.5 \\
\hline TF 9 & 0.00903 & -0.00035 & 0.00096 & 0.000506 & 90 \\
\hline TF 10 & 0.00894 & -0.00044 & 0.00101 & 0.000831 & 90 \\
\hline TF 11 & 0.00932 & -0.00006 & 0.00097 & 0.000566 & 90 \\
\hline TF 12 & 0.00873 & -0.00065 & 0.00102 & 0.000863 & 90 \\
\hline
\end{tabular}


TABLE D-4. Power and Temperature Data for Run 11

(Temperatures in Degrees C)

Normalized

Cobalt

Time, Detector

Thermocouple No.

sec Output TF 1 TF 2 TF 5 TF 6 TF 9 TF 10 TF 11 TF 12

$\begin{array}{llllllllll}0 & 1.0000 & 867 & 1124 & 703 & 935 & 878 & 1177 & 895 & 1182\end{array}$

$\begin{array}{llllllllll}3 & 0.9993 & 866 & 1124 & 704 & 936 & 877 & 1176 & 894 & 1183\end{array}$

$\begin{array}{llllllllll}6 & 1.0063 & 870 & 1128 & 705 & 936 & 880 & 1177 & 895 & 1184\end{array}$

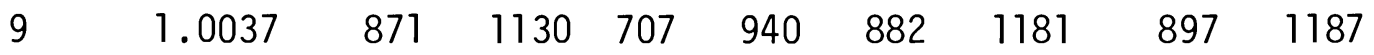

$\begin{array}{llllllllll}12 & 1.0054 & 871 & 1131 & 707 & 940 & 882 & 1182 & 898 & 1188\end{array}$

$\begin{array}{llllllllll}15 & 0.9994 & 872 & 1131 & 709 & 941 & 883 & 1183 & 899 & 1190\end{array}$

$\begin{array}{llllllllll}18 & 0.9905 & 870 & 1128 & 705 & 937 & 879 & 1180 & 897 & 1186\end{array}$

$\begin{array}{llllllllll}21 & 0.9917 & 866 & 1124 & 702 & 934 & 877 & 1176 & 892 & 1181\end{array}$

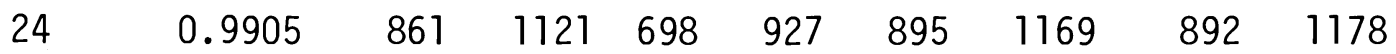

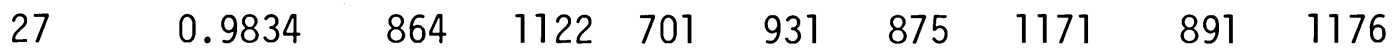

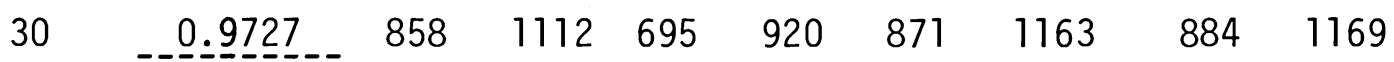

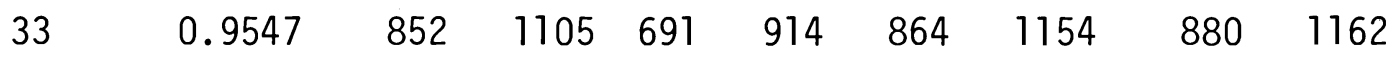

$\begin{array}{llllllllll}36 & 0.9373 & 842 & 1089 & 682 & 902 & 853 & 1140 & 872 & 1146\end{array}$

$\begin{array}{llllllllll}39 & 0.9208 & 832 & 1076 & 673 & 887 & 841 & 1124 & 859 & 1132\end{array}$

$\begin{array}{llllllllll}42 & 0.9022 & 819 & 1059 & 661 & 870 & 831 & 1103 & 848 & 1113\end{array}$

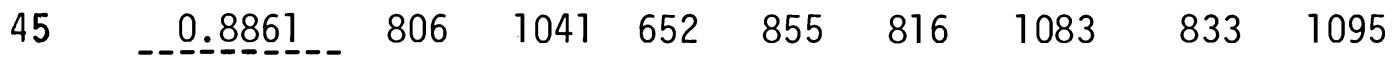

$\begin{array}{llllllllll}48 & 0.8776 & 797 & 1028 & 645 & 840 & 806 & 1066 & 823 & 1081\end{array}$

$\begin{array}{llllllllll}51 & 0.8676 & 789 & 1017 & 638 & 831 & 797 & 1052 & 812 & 1067\end{array}$

$\begin{array}{llllllllll}54 & 0.8576 & 781 & 1009 & 635 & 823 & 790 & 1041 & 806 & 1058\end{array}$

$\begin{array}{llllllllll}57 & 0.8469 & 777 & 1002 & 632 & 818 & 786 & 1031 & 800 & 1050\end{array}$

$\begin{array}{llllllllll}60 & 0.8432 & 771 & 996 & 628 & 812 & 780 & 1022 & 796 & 1042\end{array}$

$\begin{array}{llllllllll}63 & 0.8359 & 767 & 991 & 625 & 806 & 775 & 1013 & 789 & 1037\end{array}$

D. 5 
TABLE D-5. Normalized Temperature Data for Run 11

Time, Thermocouple No.

\begin{tabular}{|c|c|c|c|c|c|c|c|c|}
\hline e, & TF 1 & TF 2 & TF 5 & TF 6 & TF 9 & IF 10 & IF 11 & TF 12 \\
\hline 0 & 00 & 000 & 1.0000 & 000 & 000 & 00 & 0 & 70000 \\
\hline 3 & 0.9984 & $1.0000^{\circ}$ & 1.0022 & 1.0014 & 0.9984 & 0.9989 & 0.9985 & 1.0011 \\
\hline 6 & 1.0048 & 1.0045 & 1.0043 & 1.0014 & .0031 & 1.0000 & 1.0000 & 1.0021 \\
\hline 9 & 1.0064 & 1.0068 & 1.0086 & 1.0072 & 1.0063 & 1.0043 & 1.0031 & 1.0053 \\
\hline 12 & 1.0064 & 1.0079 & 1.0086 & 1.0072 & 1.0063 & 1.0053 & 1046 & 1.0064 \\
\hline 15 & 80 & 79 & 30 & 086 & 078 & 64 & 61 & 085 \\
\hline 18 & 1.0048 & 1.0045 & 1.0043 & 1.0029 & 1.0016 & 1.0032 & 1.0031 & 1.0042 \\
\hline 21 & 0.9984 & 1.0000 & 0.9978 & 0.9986 & 0.9984 & 0.9989 & 0.9954 & 0.9989 \\
\hline 24 & 904 & 0.9966 & 0.9892 & 0.9885 & 0.9953 & & 0. & 958 \\
\hline 27 & 0.9952 & 0.9977 & 0.9957 & 0.9942 & 0.9953 & 0.9936 & 0.9939 & 0.9943 \\
\hline 30 & 0.9856 & 0.9864 & 0.9827 & …9784 & 0.9875 & 0.9851 & 0.9832 & 0.9857 \\
\hline 33 & _- 9761 & 0.9785 & 0.9741 & 0.9698 & 0.9781 & - $0.97 \underline{5} 5$ & 0.9771 & 0.9783 \\
\hline 36 & 601 & 0.9604 & 0.9546 & 0.9525 & 0.9608 & 0.9605 & & 618 \\
\hline 39 & 0.9442 & 0.9457 & 0.9352 & 0.9309 & 0.9420 & 0.9434 & 0.9450 & 0.9469 \\
\hline 42 & 0.9234 & 0.9265 & 0.9092 & 0.9069 & 0.9263 & 0.9210 & 0.9282 & 0.9268 \\
\hline 45 & _o. 9027 & ㅇ..906] & _0.8898 & 0.8849 & 0.9028 & - 0.8997 & 0.9053 & 0.9076 \\
\hline 48 & 884 & 0.8914 & 0.8747 & & 0.8871 & 0.8815 & 0.8901 & 0.8928 \\
\hline 51 & 0.8756 & 0.8790 & 0.8596 & 0.8504 & 0.8730 & 0.8666 & 0.8733 & 0.8779 \\
\hline 54 & 0.8628 & 0.8699 & 0.8531 & 0.8388 & 0.8621 & $0.8549 r$ & 0.8641 & 0.8684 \\
\hline 57 & 0.8565 & 0.8620 & 0.8467 & 0.8317 & 0.8558 & 0.8442 & 0.8550 & 0.8599 \\
\hline 60 & 0.8469 & 0.8552 & 0.8380 & 0.8230 & 0.8464 & 0.8346 & 0.8489 & 0.8519 \\
\hline 63 & 0.8405 & 0.8495 & 0.8315 & 0.8144 & 0.8386 & 0.8250 & 0.8382 & 0.8461 \\
\hline
\end{tabular}


TABLE D-6. Regression Results for Run 11

\begin{tabular}{|c|c|c|c|c|c|}
\hline $\begin{array}{c}\text { Data } \\
\text { Source } \\
\end{array}$ & $\begin{array}{c}\text { Slope of } \\
\text { Best-Fit Line, } \\
\text { Sec }^{-1} \\
\end{array}$ & $\begin{array}{c}\text { Slope } \\
\text { Difference, } \\
\text { Sec }^{-1} \\
\end{array}$ & $\begin{array}{l}\text { Significant } \\
\text { Slope } \\
\text { Difference, } \\
\text { Sec }^{-1} \\
\end{array}$ & $\begin{array}{l}\text { Residual } \\
\text { Standard } \\
\text { Deviation, } \\
\text { Sec-1 } \\
\end{array}$ & $\begin{array}{l}\text { Adjusted } \\
\text { Mean Square } \\
\text { for Tjme, } \\
\text { sec }^{2}\end{array}$ \\
\hline $\begin{array}{l}\text { Cobalt } \\
\text { Detector }\end{array}$ & 0.00583 & -- & -- & 0.000545 & 90 \\
\hline TF 1 & 0.00643 & +0.00060 & 0.00128 & 0.00187 & 45 \\
\hline TF 2 & 0.00607 & +0.00024 & 0.00115 & 0.00166 & 45 \\
\hline TF 5 & 0.00713 & +0.00130 & 0.00135 & 0.00207 & 90 \\
\hline TF 6 & 0.00723 & +0.00140 & 0.00121 & 0.00191 & 157.5 \\
\hline TF 9 & 0.00632 & +0.00049 & 0.00123 & 0.00180 & 45 \\
\hline TF 10 & 0.00683 & +0.00100 & 0.00123 & 0.00180 & 45 \\
\hline TF 11 & 0.00652 & +0.00069 & 0.00130 & 0.00191 & 45 \\
\hline TF 12 & 0.00669 & +0.00086 & 0.00181 & 0.00273 & 45 \\
\hline
\end{tabular}


TABLE D-7. Power and Temperature Data for Run 13

Normalized

Cobalt

Time, Detector Thermocouple No.

\begin{tabular}{|c|c|c|c|c|c|c|c|c|c|}
\hline $\mathrm{sec}$ & nut & $\overline{\mathrm{IF}} 1$ & IF 2 & IF 5 & TF 6 & IF 9 & TF 10 & IF 11 & IF 12 \\
\hline 0 & 1.0000 & 828 & 1027 & 671 & 881 & 825 & 1082 & 855 & 1108 \\
\hline 3 & 1.0 & 29 & 1029 & 672 & 883 & 827 & 1083 & 856 & 1109 \\
\hline 6 & 1.0075 & 28 & 1027 & 672 & 882 & 826 & 1083 & 856 & 1109 \\
\hline 9 & 0 & 9 & 1026 & 672 & 882 & 827 & 1081 & 856 & 109 \\
\hline 12 & & 24 & 1020 & 668 & 875 & 821 & 1075 & 852 & 102 \\
\hline 15 & & 6 & 1009 & 660 & 862 & 812 & 1062 & 845 & 1092 \\
\hline 18 & 0 & 805 & 993 & 650 & 847 & 801 & 1043 & 833 & 1074 \\
\hline 21 & 070 & 787 & 978 & 639 & 833 & 787 & 1025 & 816 & 1053 \\
\hline 24 & & 777 & 960 & 631 & 821 & 772 & 1008 & 803 & 1036 \\
\hline 27 & & 765 & 945 & 622 & 803 & 762 & 985 & 790 & 1014 \\
\hline 30 & 0.8451 & 750 & 926 & 612 & 791 & 748 & 964 & 777 & 994 \\
\hline 33 & 0.8241 & 739 & 909 & 603 & 776 & 734 & 943 & 763 & 973 \\
\hline 36 & 0.809 & 728 & 893 & 594 & 761 & 723 & 925 & 749 & 953 \\
\hline 39 & 0.8173 & 720 & 883 & 590 & 756 & 716 & 910 & 742 & 940 \\
\hline 42 & 0.8079 & 714 & 877 & 588 & 752 & 709 & 900 & 735 & 930 \\
\hline 45 & 0.7902 & 707 & 868 & 582 & 745 & 703 & 889 & 727 & 919 \\
\hline
\end{tabular}


TABLE D-8. Normalized Temperature Data for Run 13

\begin{tabular}{|c|c|c|c|c|c|c|c|c|}
\hline \multirow{2}{*}{$\begin{array}{l}\text { Time, } \\
\text { Sec }\end{array}$} & \multicolumn{8}{|c|}{ ermocouple No. } \\
\hline & TF 1 & TF 2 & TF 5 & TF 6 & TF 9 & TF 10 & TF 11 & IF 12 \\
\hline 0 & 1.0000 & 1.0000 & 1.0000 & 1.0000 & 1.0000 & 1.0000 & 1.0000 & 1.0000 \\
\hline 3 & 1.0017 & 1.0 & 023 & 1.0031 & 1.0034 & 12 & 16 & 012 \\
\hline 6 & 1.0000 & 1.0000 & 1.0023 & 1.0016 & 1.0017 & 12 & 16 & 1.0012 \\
\hline 9 & 1.0017 & 0.9988 & 1.0023 & 1.0016 & 1.0034 & 0 . & & 1.0012 \\
\hline 12 & & & & & 32 & & & \\
\hline 15 & 0.9796 & 0.9771 & 0.9745 & 0.9704 & 0.9778 & & & \\
\hline 18 & 0.9609 & 0.9568 & 0.9513 & 0.9470 & 0.9590 & 0.9537 & 0.9642 & 0.9608 \\
\hline 21 & 0 & 0.9 & 58 & 0.9251 & 0.9350 & & & \\
\hline 24 & 0.9133 & 0.9149 & 0.9072 & 0.9064 & 0.9094 & & & \\
\hline 27 & 0.8929 & 0.8958 & 0.8863 & 0.8783 & 0.8923 & 48 & 13 & 0 \\
\hline 30 & 0.8673 & 0.8717 & 0.8631 & 0.8596 & 0.8684 & 0.8599 & $0 . \varepsilon$ & 0.8687 \\
\hline 33 & 0.8486 & 0.8501 & 0.8422 & 0.8362 & 0.8444 & 0.8349 & 0.8504 & 0.8445 \\
\hline 36 & 0.8299 & 으요 & 요요느. & & $\underline{0.8256}$ & & & \\
\hline 39 & 0.8163 & 0.8170 & 0.8121 & 0.8050 & 0.8137 & 0.7957 & 0.8163 & 0.8065 \\
\hline 42 & 0.8061 & 0.8094 & 0.8074 & 0.7988 & 0.8017 & 0.7838 & 0.8049 & 0.7949 \\
\hline 45 & 0.7974 & 0.7980 & 0.7935 & 0.7878 & 0.7915 & 0.7708 & 0.7919 & 0.7823 \\
\hline
\end{tabular}


TABLE D-9. Regression Results for Run 13

\begin{tabular}{|c|c|c|c|c|c|}
\hline $\begin{array}{l}\text { Data } \\
\text { Source } \\
\end{array}$ & $\begin{array}{c}\text { Slope of } \\
\text { Best-Fit Line, } \\
\quad \text { Sec-1 }^{-1}\end{array}$ & $\begin{array}{c}\text { Slope } \\
\text { Difference, } \\
\text { sec }^{-1} \\
\end{array}$ & $\begin{array}{c}\text { Significant } \\
\text { Slope } \\
\text { Difference, } \\
\text { sec }^{-1} \\
\end{array}$ & $\begin{array}{l}\text { Residual } \\
\text { Standard } \\
\text { Deviation, } \\
\text { sec- }^{-1} \\
\end{array}$ & $\begin{array}{c}\text { Adjusted } \\
\text { Mean Square } \\
\text { for Time, } \\
\text { sec } 2 \\
\end{array}$ \\
\hline $\begin{array}{c}\text { Cobalt } \\
\text { Detector }\end{array}$ & 0.00705 & -- & -- & 0.00182 & 540 \\
\hline TF 1 & 0.00722 & +0.00017 & 0.00138 & 0.00316 & 378 \\
\hline TF 2 & 0.00707 & +0.00002 & 0.00089 & 0.00138 & 378 \\
\hline TF 5 & 0.00725 & +0.00020 & 0.00095 & 0.00167 & 378 \\
\hline TF 6 & 0.00742 & +0.00037 & 0.00094 & 0.00181 & 540 \\
\hline TF 9 & 0.00736 & +0.00031 & 0.00105 & 0.00205 & 378 \\
\hline TF 10 & 0.00784 & +0.00079 & 0.00113 & 0.00233 & 378 \\
\hline TF 11 & 0.00743 & +0.00038 & 0.00096 & 0.00170 & 378 \\
\hline TF 12 & 0.00767 & +0.00062 & 0.00090 & 0.00145 & 378 \\
\hline
\end{tabular}


TABLE D-10. Power and Temperature Data for Run 17

Normalized

Cobalt

\begin{tabular}{l} 
Time, $\begin{array}{c}\text { Detector } \\
\text { sec } \\
\text { Output }\end{array}$ \\
\hline
\end{tabular}

$\begin{array}{llllllllll}0 & 1.0000 & 838 & 1039 & 679 & 892 & 834 & 1098 & 864 & 1127\end{array}$

$\begin{array}{llllllllll}3 & 1.0060 & 837 & 1040 & 678 & 893 & 835 & 1099 & 865 & 1126\end{array}$

$\begin{array}{llllllllll}6 & 1.0089 & 840 & 1044 & 680 & 895 & 835 & 1102 & 866 & 1130\end{array}$

$\begin{array}{llllllllll}9 & -0.9930 & 840 & 1043 & 681 & 896 & 834 & 1102 & 866 & 1128\end{array}$

$\begin{array}{llllllllll}12 & 0.9685 & 832 & 1033 & 676 & 887 & 827 & 1092 & 859 & 1120\end{array}$

$\begin{array}{llllllllll}15 & 0.9399 & 821 & 1021 & 664 & 872 & 817 & 1076 & 848 & 1106\end{array}$

$\begin{array}{llllllllll}18 & 0.9090 & 805 & 999 & 652 & 854 & 803 & 1054 & 834 & 1085\end{array}$

$\begin{array}{llllllllll}21 & 0.8757 & 789 & 979 & 638 & 833 & 786 & 1029 & 817 & 1061\end{array}$

$\begin{array}{llllllllll}24 & 0.8408 & 771 & 955 & 623 & 813 & 766 & 1002 & 798 & 1034\end{array}$

$\begin{array}{llllllllll}27 & -0.8115 & 752 & 930 & 610 & 790 & 747 & 970 & 777 & 1001\end{array}$

$\begin{array}{llllllllll}30 & 0.7923 & 732 & 904 & 596 & 769 & 728 & 939 & 756 & 970\end{array}$

$\begin{array}{llllllllll}33 & 0.7923 & 720 & 887 & 587 & 755 & 715 & 918 & 742 & 949\end{array}$

$\begin{array}{llllllllll}36 & 0.7923 & 712 & 878 & 584 & 749 & 707 & 904 & 734 & 935\end{array}$

$\begin{array}{llllllllll}39 & 0.7844 & 706 & 871 & 582 & 744 & 703 & 894 & 727 & 925\end{array}$

$\begin{array}{llllllllll}42 & 0.7801 & 699 & 865 & 577 & 740 & 695 & 885 & 719 & 917\end{array}$ 
TABLE D-11. Normalized Temperature Data for Run 17

\begin{tabular}{|c|c|c|c|c|c|c|c|c|}
\hline \multirow{2}{*}{$\begin{array}{c}\text { Time, } \\
\text { sec } \\
\end{array}$} & \multicolumn{8}{|c|}{ Thermocoup le No. } \\
\hline & TF 1 & TF 2 & TF 5 & TF 6 & TF 9 & TF 10 & TF 11 & TF 12 \\
\hline 0 & 1.0000 & 1.0000 & 1.0000 & 1.0000 & 1.0000 & 1.0000 & 1.0000 & 1.0000 \\
\hline 3 & 0.9983 & 1.0013 & 0.9977 & 1.0015 & 1.0017 & 12 & 16 & 989 \\
\hline 6 & 1.0033 & 1.0063 & 1.0023 & 1.0046 & 1.0017 & 1.0047 & 32 & 034 \\
\hline 9 & & 050 & 1.0046 & 1. & 000 & 47 & & \\
\hline 12 & & 5 & $\underline{0.993} 2$ & 23 & & & & \\
\hline 15 & & & 58 & & 14 & 44 & & \\
\hline 18 & 0.9448 & 0.9499 & 0.9385 & 0.9417 & 0.9478 & 87 & & \\
\hline 21 & $0 . c$ & 49 & 0.9066 & & 0.9192 & 96 & & 256 \\
\hline 24 & 0.8880 & 0.8949 & 0.8724 & & 0.8855 & & & \\
\hline 27 & - $-2.856 \underline{2}$ & -0.8636 & -0.8428 & -0.8436 & 0.8535 & 08 & $-\underline{0}=\underline{\varepsilon}$ & \\
\hline 30 & 0.8227 & 0.8310 & 0.8109 & 0.8113 & 0.8215 & 147 & 69 & 3230 \\
\hline 33 & 0.8027 & 0.8098 & 0.7904 & 0.7899 & 0.7997 & 0.7902 & 0.8045 & 0.7993 \\
\hline 36 & 0.7893 & 0.7985 & 0.7836 & 0.7807 & 0.7862 & 0.7739 & 0.7917 & 0.7835 \\
\hline 39 & 0.7793 & 0.7897 & 0.7790 & 0.7730 & 0.7795 & 0.7622 & 0.7804 & 0.7723 \\
\hline 42 & 0.7676 & 0.7822 & 0.7677 & 0.7669 & 0.7660 & 0.7517 & 0.7676 & 0.7632 \\
\hline
\end{tabular}


TABLE D-12. Regression Results for Run 17

\begin{tabular}{|c|c|c|c|c|c|}
\hline $\begin{array}{c}\text { Data } \\
\text { Source } \\
\end{array}$ & $\begin{array}{c}\text { Slope of } \\
\text { Best-Fit Line, } \\
\mathrm{sec}^{-1}\end{array}$ & $\begin{array}{c}\text { Slope } \\
\text { Difference, } \\
\text { Sec }^{-1} \\
\end{array}$ & $\begin{array}{c}\text { Significant } \\
\text { Slope } \\
\text { Difference, } \\
\text { sec-1 }^{-1} \\
\end{array}$ & $\begin{array}{l}\text { Residual } \\
\text { Standard } \\
\text { Deviation, } \\
\text { Sec-1 }^{-1} \\
\end{array}$ & $\begin{array}{l}\text { Adjusted } \\
\text { Mean Square } \\
\text { for Time, } \\
\text { sec }^{2} \\
\end{array}$ \\
\hline $\begin{array}{c}\text { Cobalt } \\
\text { Detector }\end{array}$ & 0.01062 & -- & -- & 0.00202 & 157.5 \\
\hline TF 1 & 0.00986 & -0.00076 & 0.00182 & 0.00182 & 45 \\
\hline TF 2 & 0.00963 & -0.00099 & 0.00197 & 0.00230 & 45 \\
\hline TF 5 & 0.01040 & -0.00022 & 0.00164 & 0.00201 & 90 \\
\hline TF 6 & 0.01048 & -0.00014 & 0.00174 & 0.00227 & 90 \\
\hline TF 9 & 0.01055 & -0.00007 & 0.00176 & 0.00161 & 45 \\
\hline TF 10 & 0.01084 & +0.00022 & 0.00220 & 0.00295 & 45 \\
\hline TF 11 & 0.01015 & -0.00047 & 0.00195 & 0.00226 & 45 \\
\hline TF 12 & 0.01052 & -0.00010 & 0.00256 & 0.00383 & 45 \\
\hline
\end{tabular}


TABLE D-13. Power and Temperature Data for Run 21

Normalized

Cobalt

Time, Detector Thermocouple No.

sec Output TF 1 TF 2 TF 5 TF 6 TF 9 TF 10 TF 11 IF 12

$\begin{array}{llllllllll}0 & 1.0000 & 884 & 1126 & 713 & 974 & 878 & 1211 & 917 & 1223\end{array}$

$\begin{array}{llllllllll}3 & 0.9717 & 882 & 1126 & 713 & 974 & 876 & 1209 & 917 & 1221\end{array}$

$\begin{array}{llllllllll}6 & -0.9440 & 878 & 1119 & 709 & 967 & 874 & 1204 & 913 & 1215\end{array}$

$\begin{array}{llllllllll}9 & 0.9257 & 872 & 1107 & 702 & 955 & 867 & 1193 & 906 & 1205\end{array}$

$\begin{array}{llllllllll}12 & 0.8949 & 860 & 1093 & 692 & 941 & 854 & 1176 & 894 & 1187\end{array}$

$\begin{array}{llllllllll}15 & 0.8628 & 845 & 1075 & 681 & 922 & 840 & 1153 & 881 & 1167\end{array}$

$\begin{array}{llllllllll}18 & 0.8377 & 832 & 1055 & 669 & 904 & 825 & 1132 & 866 & 1148\end{array}$

$\begin{array}{llllllllll}21 & 0.8075 & 816 & 1035 & 658 & 885 & 810 & 1107 & 851 & 1127\end{array}$

$\begin{array}{llllllllll}24 & -0.7710 & 796 & 1011 & 645 & 864 & 792 & 1076 & 832 & 1099\end{array}$

$\begin{array}{llllllllll}27 & 0.7540 & 779 & 985 & 629 & 841 & 772 & 1043 & 811 & 1070\end{array}$

$\begin{array}{llllllllll}30 & 0.7421 & 760 & 963 & 617 & 823 & 753 & 1013 & 791 & 1044\end{array}$

$\begin{array}{llllllllll}33 & 0.7421 & 744 & 943 & 607 & 807 & 736 & 986 & 774 & 1019\end{array}$

$\begin{array}{llllllllll}36 & 0.7400 & 735 & 930 & 601 & 796 & 726 & 968 & 763 & 1001\end{array}$ 
TABLE D-14. Normalized Temperature Data for Run 21

\begin{tabular}{|c|c|c|c|c|c|c|c|c|}
\hline \multirow{2}{*}{$\begin{array}{c}\text { Time, } \\
\text { sec }\end{array}$} & \multicolumn{8}{|c|}{ Thermocouple No. } \\
\hline & $F 1$ & $\mathrm{~F} 2$ & TF 5 & TF 6 & TF 9 & TF 10 & TF 11 & TF 12 \\
\hline 0 & 1.0000 & 0000 & 1.0000 & 1.0000 & 1.0000 & 1.0000 & 1.0000 & .0000 \\
\hline 3 & 69 & 100 & 00 & 0 & 969 & & & 9980 \\
\hline 6 & 07 & 21 & 15 & 0. & 937 & 28 & & 919 \\
\hline 9 & & & & & & & & \\
\hline 12 & & & & & & & & \\
\hline 15 & 0.9 & 4 & $\underline{0}$. & 0.9292 & & & & 430 \\
\hline 18 & 0 & & 0.9 & & 69 & $\underline{0}$. & -0. & 237 \\
\hline 21 & 44 & & 0.8837 & 87 & 34 & & & 023 \\
\hline 24 & & & & & & & & \\
\hline 27 & 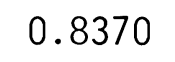 & 0.8 & 24 & 38 & 39 & & 34 & 0.8444 \\
\hline 30 & 08075 & $-\underline{0}$ & 70 & $=-$ & 41 & $\underline{0}$. & & $\cdots$ \\
\hline 33 & & & & & & & & 25 \\
\hline 36 & 0.7686 & 0.7768 & 0.7632 & 0.7575 & 0.7618 & 0.7497 & 0.7725 & 0.7742 \\
\hline
\end{tabular}


TABLE D-15. Regression Results for Run 21

\begin{tabular}{|c|c|c|c|c|c|}
\hline $\begin{array}{c}\text { Data } \\
\text { Source } \\
\end{array}$ & $\begin{array}{c}\text { Slope of } \\
\text { Best-Fit Line, } \\
\mathrm{sec}^{-1}\end{array}$ & $\begin{array}{c}\text { Slope } \\
\text { Difference, } \\
\text { Sec-1 } \\
\end{array}$ & $\begin{array}{c}\text { Significant } \\
\text { Slope } \\
\text { Difference, } \\
\text { Sec-1 } \\
\end{array}$ & $\begin{array}{l}\text { Residual } \\
\text { Standard } \\
\text { Deviation, } \\
\text { Sec-1 } \\
\end{array}$ & $\begin{array}{c}\text { Adjusted } \\
\text { Mean Square } \\
\text { for Time, } \\
\text { sec2 } \\
\end{array}$ \\
\hline $\begin{array}{c}\text { Cobalt } \\
\text { Detector }\end{array}$ & 0.01010 & -- & -- & 0.00288 & 157.5 \\
\hline TF 1 & 0.00957 & -0.00053 & 0.00230 & 0.00133 & 45 \\
\hline TF 2 & 0.00911 & -0.00099 & 0.00229 & 0.00130 & 45 \\
\hline TF 5 & 0.01007 & -0.00003 & 0.00316 & 0.00489 & 90 \\
\hline TF 6 & 0.00935 & -0.00075 & 0.00203 & 0.00185 & 90 \\
\hline TF 9 & 0.00997 & -0.00013 & 0.00224 & 0.00092 & 45 \\
\hline TF 10 & 0.01081 & +0.00070 & 0.00224 & 0.00089 & 45 \\
\hline TF 11 & 0.00989 & -0.00021 & 0.00223 & 0.00085 & 45 \\
\hline TF 12 & 0.00942 & 0.00068 & 0.00224 & 0.00093 & 45 \\
\hline
\end{tabular}


BNWL-2189

NRC- $1 \& 3$

\section{DISTRIBUTION}

No. of

Copies

OFFSITE

1 ERDA Chicago Patent Group

9800 S. Cass Avenue

Argonne, Illinois 60439

A. A. Churm

245 Basic Distribution Under NRC-1

3 ERDA Technical Information

M. Jinks

Chief Mail \& Files

US NRC Central Files

Washington, D.C. 20555

61 Supplementary NRC-3 Distribution List

10 Nuclear Regulatory Commission, Division of Reactor Safety Research Chief, Fuel Behavior Research Branch

ONSITE

$1 \quad$ ERDA Richland Operations

Office

Program Division

P. G. Holsted

$56 \quad$ Battelle-Northwest

C.R. Hann (10)

D.D. Lanning (30)

Technical Information Files (3)

Technical Publications

WJ Bailey

CL Mohr

DW Brite

FE Panisko

JA Christensen

SR Wagoner

Jo Barner

RE Williford

EL Courtright

S. Goldsmith

MD Freshley

RK Marshal1 
